\title{
Exploration and Practice of Bilingual Teaching of Financial Accounting in Colleges and Universities
}

\author{
Yang Ruoqian, Zhang Yan, Jiang Yu \\ Zhuhai College of Beijing Institute of Technology
}

Keywords: Financial accounting; Bilingual education; Exploration and practice

\begin{abstract}
In the process of promoting quality education and implementing the reform of teaching, many colleges and universities in China have started to create new teaching methods and teaching modes in combination with the actual situation of current teaching, with the aim of promoting the all-round growth and development of students as the foothold and core, and providing students with a good learning environment. This paper, based on the characteristics of the bilingual teaching rules of financial accounting in China's colleges and universities, analyzes the actual state of the teaching in the process of practice, in order to provide some reference for the effective implementation of bilingual teaching of financial accounting in China's colleges and universities.
\end{abstract}

\section{Bilingual Education}

There are some differences between bilingual teaching and language teaching, of which the former is based on non language courses and other foreign language teaching, and coaches different linguistic disciplines through non native languages. Therefore, the connotation of bilingual teaching will be affected by regional and national influence.

Bilingual teaching mode conforms to the development demand of talent internationalization and education internationalization, which can effectively promote the promotion of China's comprehensive soft power and guarantee our country to gain more advantages in the process of market competition. However, based on the practice survey of this paper, it can be seen that many school have many misunderstandings and shortcomings in the process of practice teaching.

Schools and teachers pay too much attention to English teaching but neglect bilingual teaching. In order to promote the improvement of English teaching, most colleges and universities actively employ outstanding foreign language teachers, taking the standard and accuracy of language as a foothold and goal. Although this teaching mode can break through the shackles of English teaching in China, however, too much emphasis on the accuracy of language leads to the neglect of professional knowledge teaching. This teaching mode can promote the improvement of students' foreign language level to a certain extent. However, bilingual teaching should not only pay attention to the improvement of students' foreign language ability, but also focus on students' learning skills to ensure that students can acquire the corresponding second language ability. In addition, the connotation of bilingual teaching is relatively complex. The teaching mode is more focused on the training of students' bilingual thinking, so as to ensure that students can analyze and think about various problems under the different thinking background of the Chinese and Western countries.

Secondly, some schools and teachers pay too much attention to English teaching while neglecting mother tongue teaching. The promotion of bilingual teaching takes the cultivation of students' English practical ability as the foothold and builds a good foreign language learning atmosphere for students, but many schools often put the cart before the horse. According to the survey conducted by authoritative international organizations, students' achievements in the learning process are mainly based on their mastery of cognitive language. Only by learning the second language on the basis of the first language can we improve the cognitive ability of the individual and master the expression skills of the second language. This kind of teaching method not only seriously hinders the implementation of bilingual teaching, but also causes a lot of teaching resources to be wasted. 


\section{Connotation of Bilingual Teaching of Financial Accounting in Colleges and Universities under Competence-Oriented Model}

In the era of information and science and technology, the demand for talents is getting higher and higher in society. Many colleges and universities begin to take the competence orientation as the foothold and core, and break through the traditional teaching mode. The competence standard vocational education has been praised by many countries and regions in the process of practice. This teaching mode is based on the composition of ability, and carries out continuous reform on the existing teaching system in strict accordance with the specific connotation of the theory of ability standard.

For the financial accounting major of colleges and universities, the professional competence involved in the process of bilingual teaching includes many contents, such as the simple calculation of the profit of the enterprise according to the English information, the correct reading and writing of relevant subjects and information of Chinese and English accounting, the registration of the daily account using the accounting rules of bookkeeping method, and meanwhile students should also actively describe the data structure and basic structure of the basic financial statements.

The bilingual teaching of financial accounting in colleges and universities under the competence-oriented mode is mainly based on the development of ability. Through the scientific setting of the basic tasks of the bilingual teaching of financial accounting specialty, under the non native language environment, the comprehensive applied talents who are good at cooperation, learning and independent working can be better cultivated.

\section{The Practice of Bilingual Teaching of Financial Accounting in Colleges and Universities}

\subsection{Paying Attention to the Practical Teaching in the Teaching Procedure}

The bilingual teaching of financial accounting in colleges and universities must be based on the training of students' comprehensive operational ability to ensure that the students of this major achieve the close combination of theory and practice after completing the study of professional theoretical knowledge. While perfecting the basic teaching procedures, the school needs to ensure the reasonable proportion of the practical teaching in the whole teaching content, and pays attention to student's practice and operational ability and provides students with more opportunities to exercise.

\subsection{Paying Attention to the Diversity of Teaching Media}

In order to lay a solid foundation for practical teaching, the teachers of financial accounting major in colleges and universities must pay attention to the diversified application of teaching media in the process of bilingual teaching, and actively introduce various modern technologies, and take multimedia teaching as the basis and core to avoid the shortage of teaching resources in the bilingual teaching process. It is undeniable that the application of multimedia technology not only meets the requirements of modern education and teaching, but also can effectively make up for the students' lack of thinking and logical imagination to realize the all-round guidance to students, to simulate students' different senses, and to enable students to better realize their overall improvement of their comprehensive English ability and professional ability and accomplishment in the context of perception.

\subsection{Paying Attention to the Continuous Optimization of Teaching Materials}

In order to effectively improve the whole teaching process, optimize the teaching process and improve the students' learning effect, teachers must provide more guidance for the students and constantly optimize the existing teaching materials, of which the contents and links involved in bilingual teaching of financial accounting major in colleges and universities are relatively complicated. In addition to the need to actively break through the shackles of the language environment and ensure that students can master the essence and core of bilingual learning, teachers also need to make the students majoring in financial accounting based on the essential situation of 
the current basic professional learning, actively accept the teacher's guidance and education, and improve the individual's comprehensive professional ability in the process of continuous exploration and practice.

\section{Conclusions}

In order to ensure the all-round growth and development of students majoring in finance and accounting in the bilingual teaching process, the teachers of colleges and universities must actively provide students with more opportunities to study and exercise, and stand on the students' perspective to create a new teaching mode by strengthening the interaction with students.

\section{Acknowledgement}

This paper is a part of achievement of "Study on the construction of intermediate financial accounting (bilingual) course system based on the comparison between Chinese and foreign accounting standards" supported by 2017 Guangdong Province higher education teaching research and reform project.

\section{References}

[1] Ping Wu: A Summary of the Research on Bilingual Teaching in the Past Five Years[J], China University Teaching, 2007(01).

[2] Ying Wang and Juanjuan Yue: Promoting Bilingual Teaching and Expanding International Vision[J], China Higher Education, 2005(23).

[3] Wenying Pei and Jun Chen: The Misunderstandings, Puzzles and Countermeasures of Bilingual Teaching in Colleges and Universities[J], Jiangsu Higher Education, 2005(05).

[4] Xiaoying Teng: Exploration and Experience of Bilingual Teaching[J], China University Teaching, 2005(07).

[5] Yongqi Gu and Lianzhong Dong: The Experience, Lessons and Enlightenment of Bilingual Teaching in Hongkong[J], Modern Foreign Languages, 2005(01). 